\title{
E-Commerce Adoption at Customer Level in Jordan: an Empirical Study of Philadelphia General Supplies
}

\author{
Mohammed Al Masarweh \\ Software Engineering Department \\ Al-Balqa' Applied University \\ Salt, Jordan \\ Sultan Al-Masaeed \\ E-Business Department \\ Al Ahliyya Amman University \\ Amman, Jordan
}

\author{
Laila Al-Qaisi \\ Computer Science WISE \\ Amman, Jordan \\ Ziad Hunaiti \\ ECE department \\ Brunel university London \\ London, UK
}

\begin{abstract}
E-commerce in developing countries has been studied by numerous researchers during the last decade and a number of common and culturally specific challenges have been identified.. This study considers Jordan as a case study of a developing country where E-commerce is still in its infancy. Therefore, this research work comes as a complement to previous research and an opportunity to refine E-commerce adaptation research. This research was conducted by survey distributed randomly across branches of Philadelphia General Supplies (PGS), a small and medium enterprise (SME). The key findings in this research indicated that Jordanian society is moving towards online shopping at very low rates of adoption, due to barriers including weak infrastructure throughout the country except in the capital, societal trends and culture and educational and computer literacy. This means that E-commerce in Jordan still remains an under-developed industry.
\end{abstract}

Keywords-Information systems; E-commerce; E-commerce Adoption; E-commerce in Jordan; Jordan

\section{INTRODUCTION}

Information Technology (IT) has been significantly developing in recent decades, raising numerous opportunities and challenges in the business environment in various aspects. In a consumer context, the synergy of the internet and business operations gives more flexibility to users to identify their needs as well as respond to market developments, such as feedback and reviews about items customers have bought and their experiences [1].

Since the 2000s the popularization of personal computing and the revolution in internet communications has enabled a massive adoption of E-commerce throughout the world, correspondingly making it a major concern or researchers exploring the consumer and business implications of associated developments. While E-commerce is now firmly embedded in the economic life of most developed countries, its progress has been uneven and more complex in developing countries, thus most studies pertaining to the latter have focused on adoption factors, with a general view to exploring how E-commerce can be enhanced to promote socio-economic development.[2]
Within the global economy, essentially all financial transactions are now conducted online, and a virtual market has arisen in commercial technological innovation that supports a new channel of client-supplier transaction, which has been widely used in business-to-business transactions to greatly enhance operational cost and time efficiency; however, there is a disconnect between the significant streamlining of businessto-business operations (such as those involved in supply chain management) and business-to-customer transactions in the electronic environment, with salient differences in interactions and customer patterns.[3]

Most organizations tend to abandon traditional business formats as much as feasible where E-commerce alternatives can be adopted, but such restructuring requires coherent and appropriate strategies. However, to remain competitive in the global marketplace (and indeed in basic national economic contexts) companies of all kinds have been compelled to adopt E-commerce applications [4].

Corresponding to global trend of moving organizations into E-business, many organizations in the Hashemite Kingdom of Jordan (HKJ) had already moved, while others are studying their steps towards moving [2].

Harnessing the power of the Internet could help SMEs to address critical issues, such as: increased global competition and consumer demand for quality, rapidly changing market environment, growing need for flexibility and immediate access to business information [5].

The main concern in this study is E-commerce adoption for small and medium enterprises (SMEs) in the HKJ, investigated by an empirical study of one of those SMEs, namely Philadelphia for General Supplies.

\section{LITERATURE REVIEW}

\section{A. Electronic Commerce}

E-commerce generally refers to the integration of IT with various business activities within an organization. This plays critical role in spreading the organization's services and products beyond its local market, as well as coordinating 
internal operations and supply chain management as a whole. As a result, it helps in gaining more customer interest and other various benefits affecting targets positively [6].

Many researchers have defined E-commerce from various perspectives. Khoshnampour and Nosrati [7] gave a simple definition about selling and buying products and services through the internet or other types of networks, while [6] indicated that it is about using the internet to accomplish business transactions locally or internationally. The use of IT to conduct business transactions among buyers, sellers and other partners was the crux of the definition presented by [8], while [9] gave a more specific and subjective definition of using Web 2.0 applications to conduct undergoing commerce activities in order to improve customer participation, which results in improved satisfaction and greater economic value.

Turban et al. [10] defined E-commerce as a business model in which transactions are conducted through electronic networks (i.e. the internet), including the processes of buying and selling products, services and information. Nielson et al. [11] stated that a company can be seen as a true E-commerce venture when its major revenue is generated via the internet; the online environment is connected to all of its major processes; business operations can be undertaken 24/7; and they are always open to satisfy global customers. Secondary features include organizational structure being less centralized and less hierarchical than in traditional business models. In having these traits, a company can react to rapid changes in the digital world very quickly, whereby flexibility and the ability to execute changes are highly required.

\section{B. E-commerce adoption within an organization}

The realm of business has been profoundly revolutionized by the global spread of electronic communication technologies, particularly the internet, and their popularization and widespread use since the late 1990s. Prior to this, only large multinational corporations could afford to invest in hardware, software and skilled personnel to achieve efficiencies from investment in IT, but the increasing affordability of personal and industrial computer systems has driven the adoption of IT and E-commerce in society at large, with organized Ecommerce systems being essential to SMEs and even small companies in the modern market [12].

The work of Lippert and Govindarajulu [13] showed that successful adoption of E-commerce by any organization is based on two main factors: technology characteristics and customer understanding of the system. Nevertheless, adoption decisions within an organization are conditioned by multiple complex and often interconnected wider stakeholders in the surrounding environment, including customers, suppliers, partners, competitors and governmental regulations. This means that top managers have to study their organizational environment's current state and decide whether it is possible and economically viable to complete the adoption process, on the basis of feasibility and cost-benefit analysis [13].

Numerous different procedures are necessary for different E-commerce technology adoptions, such as websites enabling online business transactions, which require a payment platform as well as catalogue and ordering systems linked to inventory

Identify applicable sponsor/s here. If no sponsors, delete this text box (sponsors). and ordering functions. E-commerce adoption must therefore be taken seriously, with full acceptance of its complexity and potentially high investment costs from the outset. Empirical analyses have generally explored the process of adoption in terms of sequential stages, from initial awareness of the potential innovation to full integration and deployment of Ecommerce functions in organizational practices [14] and [15].

Furthermore, [16] mentioned that organizations should be aware of the necessity for a dedicated online marketing strategy in addition (or in place of) traditional marketing methods, to utilize the advantages of E-commerce to reach wider or (conversely) more targeted audiences more expediently. Traditional mass advertising, while remarkable in its day, pales in comparison to the advertising capabilities of technologies and platforms enabled by web 2.0 applications, such as social networking websites, customer reviews and suggestions, and the ability of personalizing advertisements through such interactive websites. E-commerce enables properly organized companies to seamlessly combine the functions of market research, advertising and supply chain management with online purchasing activity, with maximum cost efficiency and the most effective deployment of resources.

\section{E-commerce adoption challenges}

Despite the manifest advantages of E-commerce adoption, it cannot simply be purchased and implemented wholesale; for effective deployment, organizations must devise an adoption strategy tailored to their own needs, objectives and surrounding context. One of the main challenges is to define an effective Ecommerce model and strategy [17] and [18]; this must be done with reference to three main components: community, content and commerce, relative to the organization's industry, services and products. Chat rooms, message boards, email lists and social networking websites have been used to gain community (i.e. a large number of interested and motivated potential customers). Content includes news, descriptions or any related information that can attract potential customers, as well as customer-generated content such as product reviews, which disseminates information among their community. Commerce is represented by consumer purchase decisions for physical products or services online [17][18].

Another challenge that might appear during this migration, especially when organizations attempt to move into businessto-customer (B2C) E- commerce, is to integrate a web-based front-end ordering system with the back-end computer-based systems relating to inventory control and production planning. The web based front-end customers interface should be tightly integrated with back-end inventory computer-based systems in order to ensure the availability of requested products, and to alert the purchasing department to production planning needs, as shown in Figure 1 [18]. Other challenges that might appear are security and trust; internet experience; language; legal issues; and technology acceptance [19]

\section{E-commerce adoption in Jordan}

A few studies have focused on E-commerce adoption in Jordan; their main findings are presented in this section. The current status of E-commerce in Jordan represents a vital factor affecting this research. Al-debei [20] found that Jordan has various adequate E-commerce prerequisites, such 


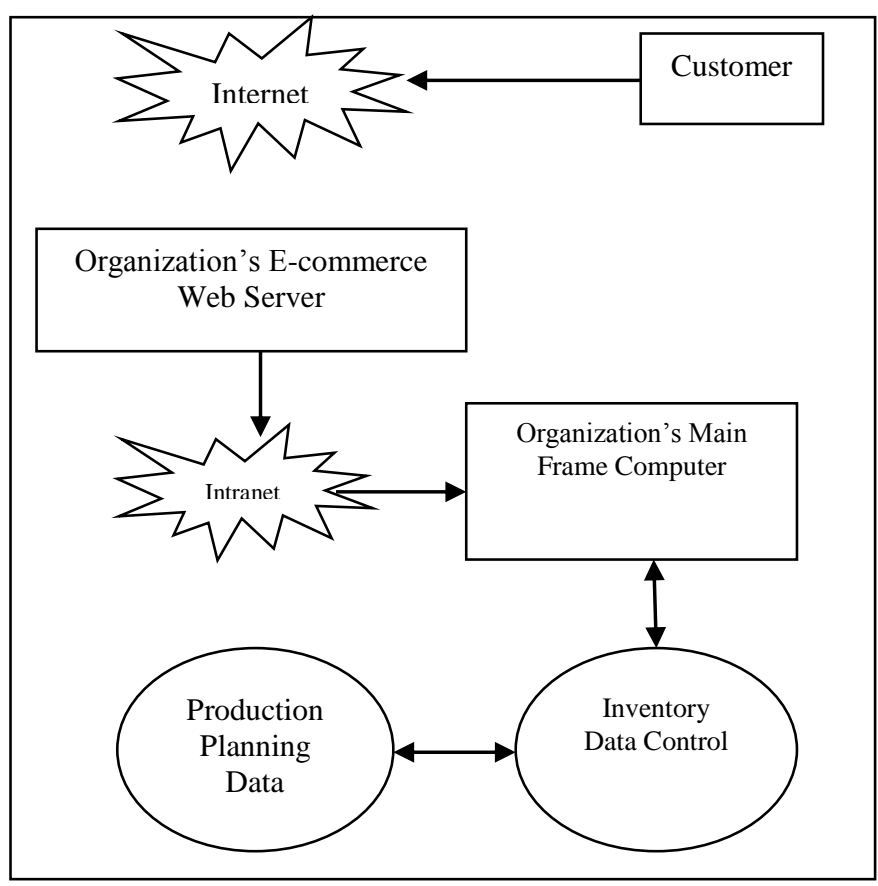

Fig. 1. Integrating web based front-end ordering system with the back-end computer based systems

as technology and telecommunication infrastructure, organizations readiness and support, institutional and governmental support and community culture. Moreover, there are sufficient IT vendors who can provide Jordanian companies with required hardware and software for their move towards Ecommerce. However, the study identified that Jordanian community culture is not germane to E-commerce adoption, and cultural beliefs and practices constitute a major impediment to this major change in the local business market. This was cited as the main reason why relatively few organizations (he specified less than 20) have developed Ecommerce in Jordan [20].

Alamro and Tarawneh [21] presented a model of the main factors in E-commerce adoption in Jordan based on three dimensions: the External Environment, the Organizational Context and the Technological Context, as shown in Figure 2.

A 2015 study [22] concluded that the effect of the adoption of e-commerce systems by SMEs in Jordan is affected particularly by the following factors: readiness, strategy, managers' perceptions and external pressure by trading partners.

A survey questionnaire was used to evaluate this model, finding that the external environment context (e.g. customer demand and quality of IT consultation services) are the main factors that affect E-commerce adoption in Jordan. In an organizational context, it has been found that employees' ICT knowledge and attitudes affect E-commerce adoption, making them either facilitators or inhibitors. In the technological context, a lack of trust in banks' support for electronic transactions, the threat of disintermediation and fear of identifying theft were the main inhibitors.
In conclusion, many factors militate against organizations' move towards E-commerce in Jordan, mainly attributable to cultural factors and a lack of trust in the security of E-payment systems.

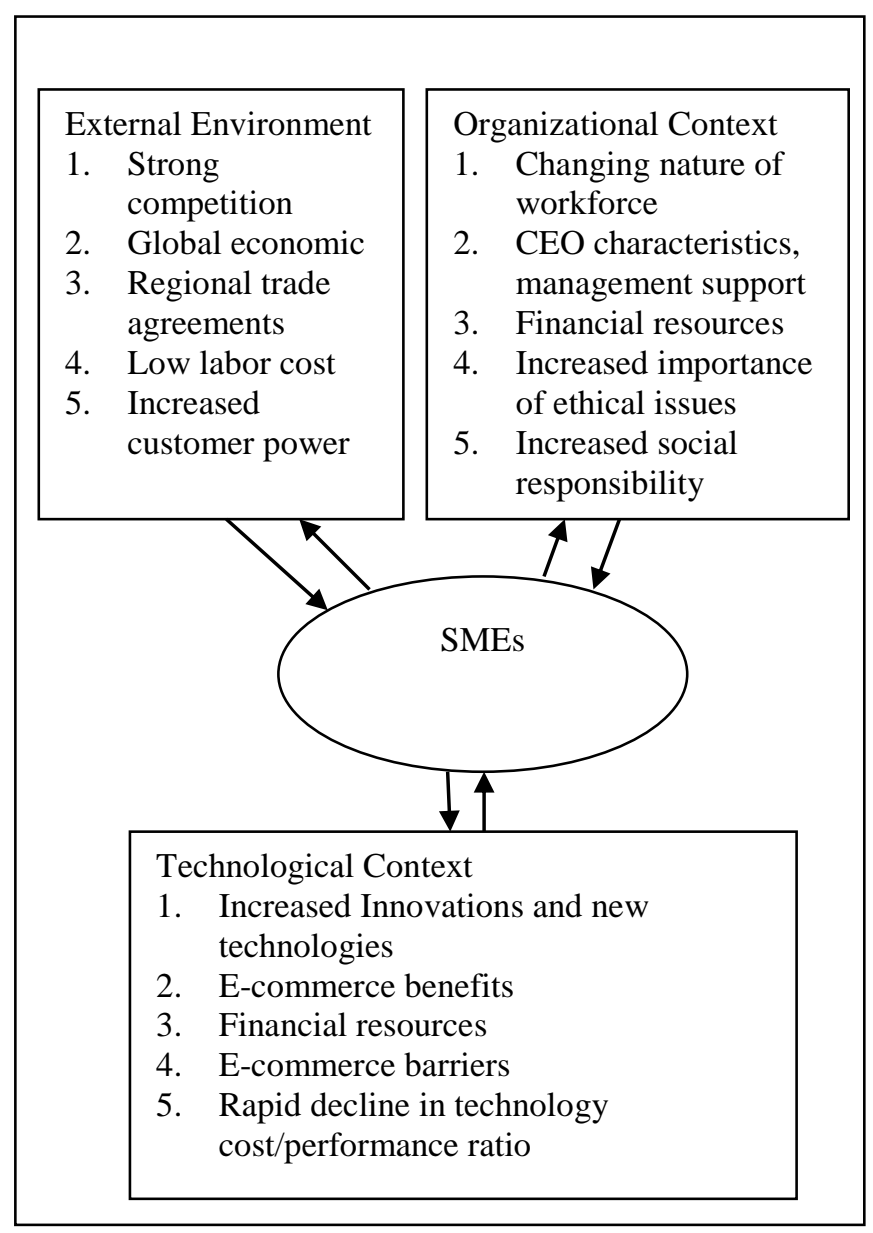

Fig. 2. A model of E-commerce adoption in SMEs

\section{RESEARCH METHODOLOGY}

\section{A. Approach}

The preceding literature review about the current status of E-commerce in Jordan has given a general idea about the main concern of this study, and indications of where to focus to explore the main factors affecting E-commerce adoption for Jordanian companies.

A set of interviews with PGS management directed the researcher to conduct a questionnaire to be answered by their customers in order to examine E-commerce adoption at a customer level, as their online shopping experience indicates the extent to which extent this major change will affect PGS's adoption of E-commerce in order to achieve intended goals. Hajli et al. [23] conducted a similar study entitled Examining E-commerce Adoption at Customer Level: The Impact of Social Commerce in Iran; his questionnaire was found to be very suitable and useful to be customized and used for measuring Jordanian customers' behavior towards online shopping. 


\section{B. Research design}

This research was conducted based on the main factors identified from a similar study in a different developing country in the Middle East. Interviews were held with top management personnel to customise the main factors for inclusion in the survey administered to intended customers in order to achieve the main goal of the study.

Questionnaire variables were concluded from interviews with top management executives. Three different locations for PGS stores were selected to distribute the questionnaires to their existing customers. The survey was designed to focus mainly on customers' opinions about online shopping and to examine their own experiences in this regard. In order to study a wide range of customers' behavior, different cultures and different age ranges were targeted by the distribution of 200 questionnaires in three locations, namely Jab AlHussien, Down Town and Al-Wehdat branches of PGS. A period of one week was given for participants recruited from each branch to return their questionnaires. A total of 189 completed responses were received, a response rate of $94.5 \%$. The results were then analyzed using SPSS. The results of statistical (quantitative) and thematic (qualitative) analysis are presented in the next chapter. Figure 3 shows the research design for this study.

\section{Questionnaire design}

The questionnaire consists of three types of questions: multiple choice,30 Likert-type questions and finally two openended questions to address major challenges towards Ecommerce adoption in Jordan from customers' perspectives.

The multiple choice questions focused on if and how customers use the internet to shop online. The Likert-type scale question addresses respondents' ability to search about requested products online, their trust of visited online shopping websites, familiarity with online shopping, familiarity with social networking websites and communities online, trusting others' reviews of certain products, the ability to provide the online vendor with required information to better serve customers' needs (i.e. market research) and respondents' opinions about learning how to use computers, browse products on the internet and shop online.

Furthermore, it addressed respondents' opinions of websites' flexibility, simplicity, ease to interaction and sociability, as well as the particular issue of their feelings concerning using credit cards to shop online.

\section{Evaluation of results}

The survey aimed to understand the attitudes of Jordanian customers towards E-commerce adoption and their ability to shop online. The results of this questionnaire helped to have a broad overview of PGS customers' experiences and perspectives towards online shopping as a rudimentary example of general Jordanian E-commerce customers (actual and potential). Moreover, measuring customers' ability to understand and deal with online websites, the internet, computers and Social Network Service (SNS) generally would indicate their willingness to deal with PGS's migration process towards E-commerce.

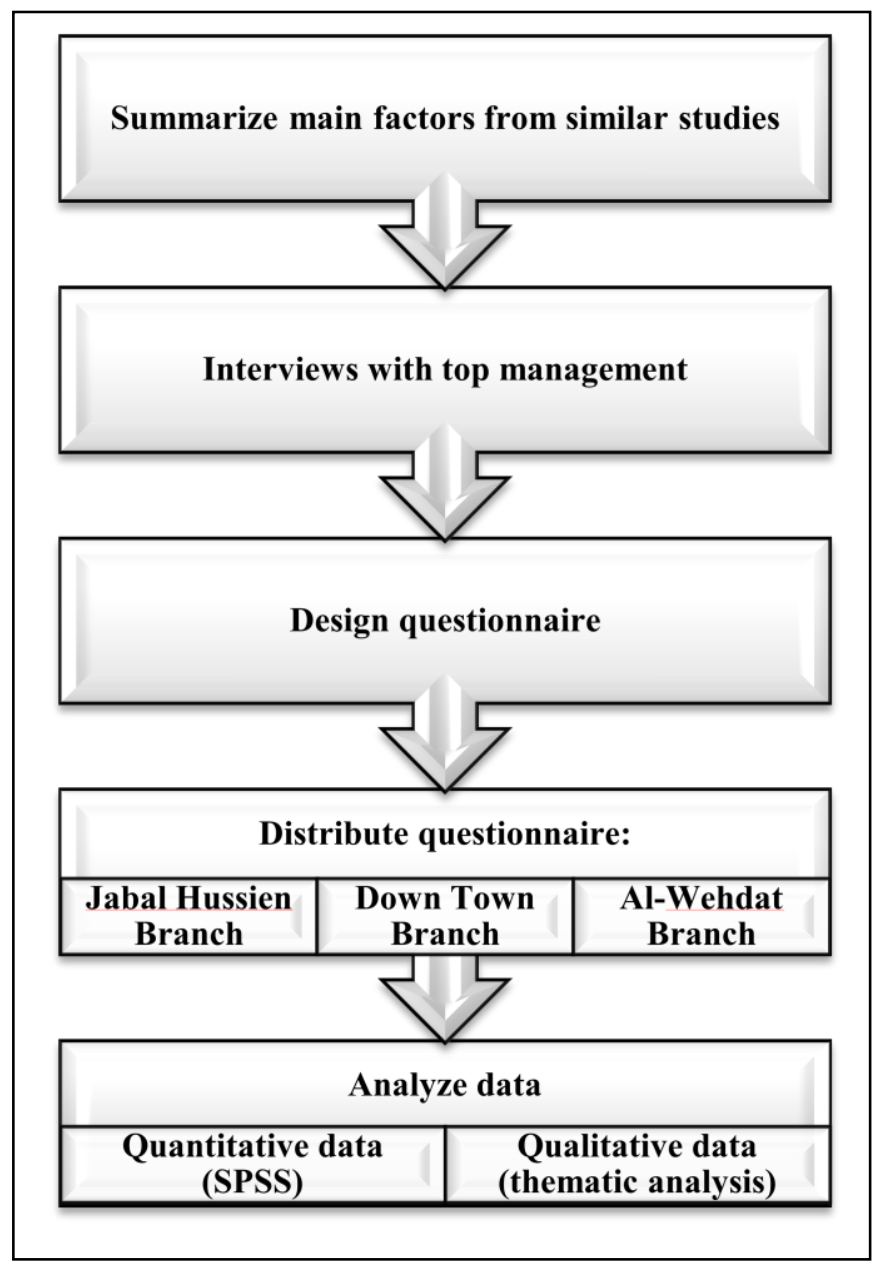

Fig. 3. Research design

\section{RESULTS}

As explained in the previous chapter, a survey questionnaire was administered been conducted to measure Ecommerce adoption at the customer level in Jordanian society, considering customers of PGS as a case study of Jordanian Ecommerce customers. This helped in understanding the current status of online shopping in Jordanian society and the extent to which Jordanian organizations would benefit from developing their E-commerce activities. Most of the survey items comprised Likert-type questions, an example of which is illustrated below in Table I.

\section{TABLE I. EXAMPLE OF LIKERT STATEMENT USED IN THIS RESEARCH}

\begin{tabular}{|l|l|l|l|l|}
\hline $\begin{array}{l}\text { Promises made by the website that has used for the last online } \\
\text { shopping are likely to be reliable }\end{array}$ \\
\hline $\begin{array}{l}\text { Strongly } \\
\text { agree }\end{array}$ & Agree & Neutral & Disagree & $\begin{array}{l}\text { Strongly } \\
\text { disagree }\end{array}$ \\
\hline 1 & 2 & 3 & 4 & 5 \\
\hline
\end{tabular}

\section{A. Reliability}

The Cronbach's (t-test) alpha test was used to ascertain the reliability of this research. The Cronbach's alpha value was 0.906 , which is above the 0.70 threshold, indicating adequate internal consistency. 


\section{B. Participants description}

Participants comprise a convenience sample of190 adults, all of whom $(100 \%)$ are Jordanian citizens, comprising 126 females and 74 males, as illustrated below in Figure 4.The majority of participants were aged 20-25 years old, as illustrated in Figure 5, and the majority held a bachelor's degree and have no online shopping experience, as illustrated in Figures 6-7.

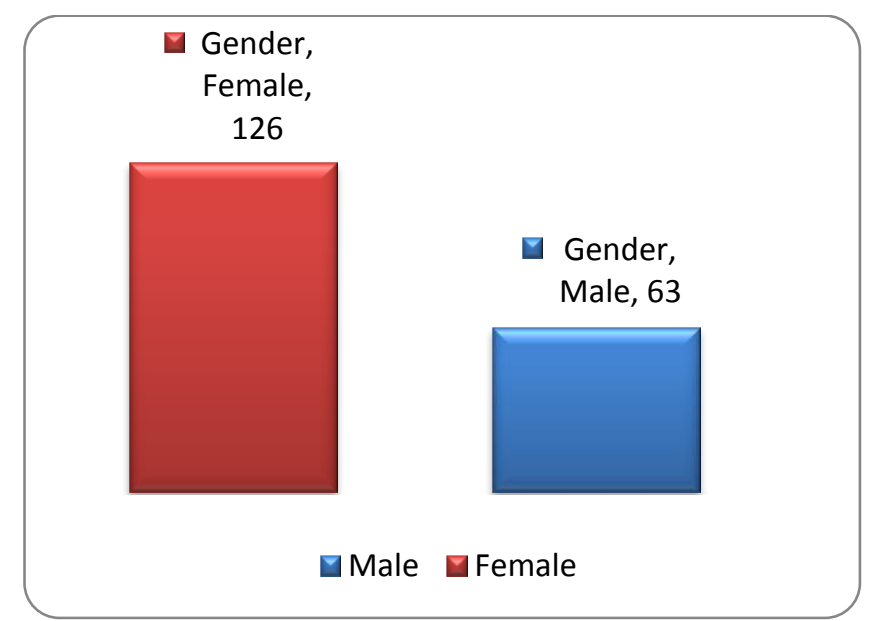

Fig. 4. Sample gender

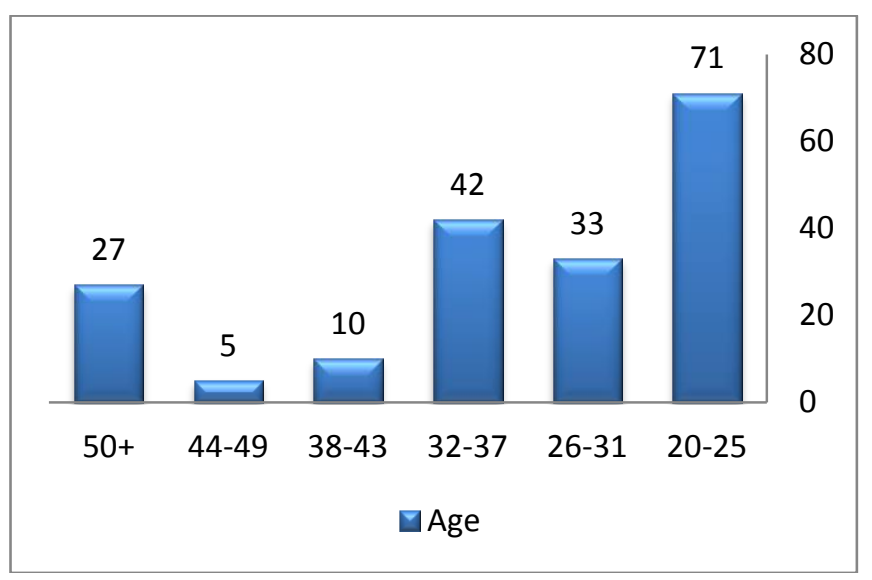

Fig. 5. Sample age (yrs)

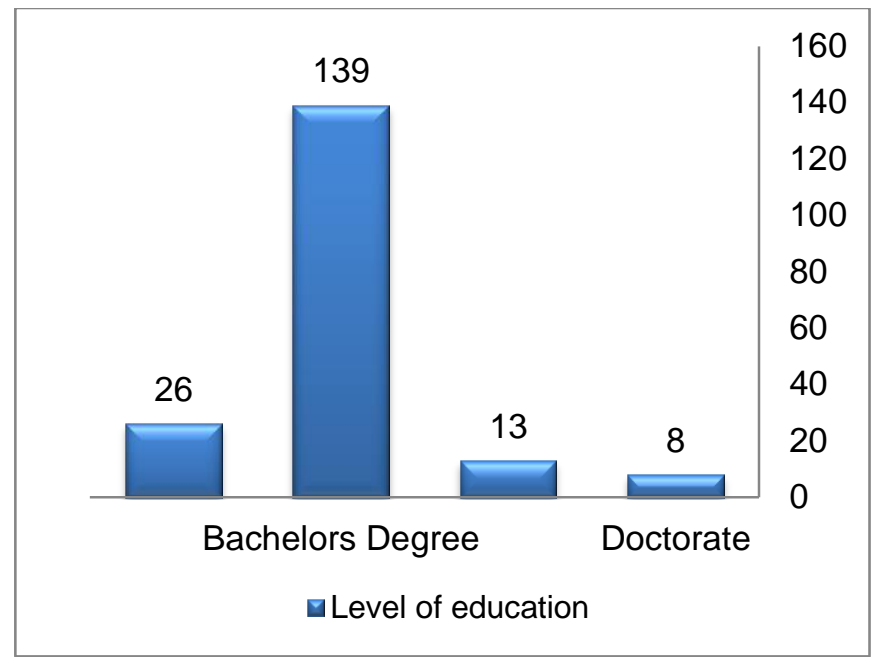

Fig. 6. Sample level of education

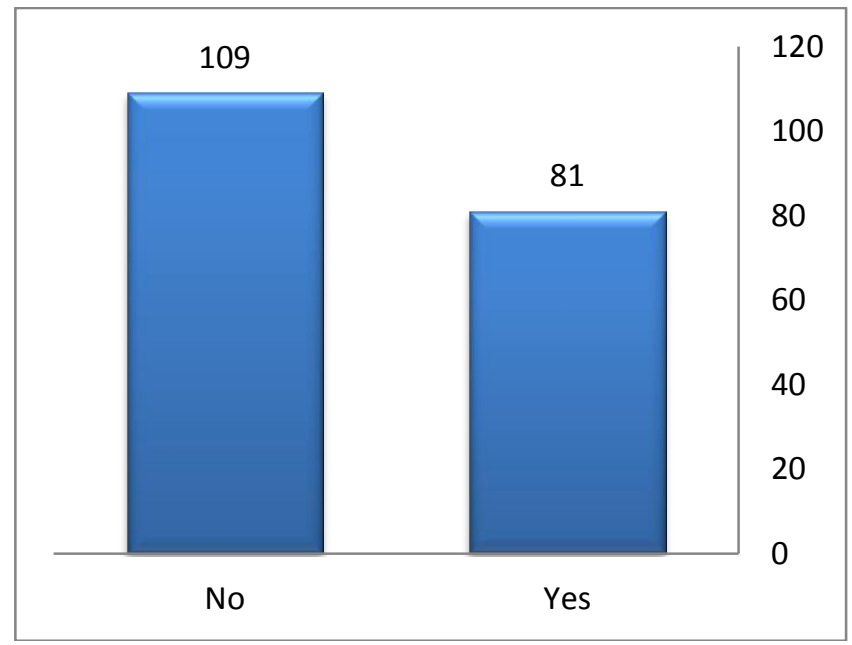

Fig. 7. Sample experience of online shopping

C. Ability to search about desired product online variable

Results indicate that Jordanians agree that searching and buying on the internet is useful, and they are familiar with internet searching for shopping purposes. 
TABLE II. SeCtion 1 - Ability to SEARCh ABout DesiRed Product ONLINE

\begin{tabular}{|c|c|c|c|c|c|c|c|c|c|c|c|}
\hline \multicolumn{2}{|c|}{$\begin{array}{l}\text { Strongl } \\
\text { y agree }\end{array}$} & \multicolumn{2}{|c|}{ Agree } & \multicolumn{2}{|c|}{ Neutral } & \multicolumn{2}{|c|}{ Disagree } & \multicolumn{2}{|c|}{$\begin{array}{l}\text { Strongly } \\
\text { disagree }\end{array}$} & \multirow{2}{*}{$\begin{array}{l}\text { Mea } \\
\text { n }\end{array}$} & \multirow{2}{*}{ SD } \\
\hline $\mathrm{N}$ & $\%$ & $\mathrm{~N}$ & $\%$ & $\mathrm{~N}$ & $\%$ & $\mathrm{~N}$ & $\%$ & $\mathrm{~N}$ & $\%$ & & \\
\hline \multicolumn{12}{|c|}{ 1. Searching and buying on the internet is useful for me } \\
\hline 0 & .0 & 6 & $\begin{array}{l}7 . \\
4\end{array}$ & $\begin{array}{l}1 \\
3\end{array}$ & $\begin{array}{l}16 . \\
0\end{array}$ & $\begin{array}{l}2 \\
4\end{array}$ & $\begin{array}{l}29 . \\
6\end{array}$ & $\begin{array}{l}33 \\
8\end{array}$ & $\begin{array}{l}46 . \\
9\end{array}$ & 4.16 & $\begin{array}{l}0.9 \\
6\end{array}$ \\
\hline \multicolumn{12}{|c|}{ 2. Searching and buying on the internet makes my life easier } \\
\hline 2 & 2.5 & 2 & $\begin{array}{l}2 . \\
5 \\
\end{array}$ & $\begin{array}{l}1 \\
5 \\
\end{array}$ & $\begin{array}{l}18 . \\
5 \\
\end{array}$ & $\begin{array}{l}3 \\
6 \\
\end{array}$ & $\begin{array}{l}44 . \\
4 \\
\end{array}$ & $\begin{array}{l}2 \\
6 \\
\end{array}$ & $\begin{array}{l}32 . \\
1 \\
\end{array}$ & 4.01 & $\begin{array}{l}0.9 \\
2 \\
\end{array}$ \\
\hline \multicolumn{12}{|c|}{ 3. I am familiar with searching for materials on the internet } \\
\hline 2 & 2.5 & 1 & $\begin{array}{l}1 . \\
3\end{array}$ & $\begin{array}{l}2 \\
2\end{array}$ & $\begin{array}{l}27 . \\
8\end{array}$ & $\begin{array}{l}2 \\
9\end{array}$ & $\begin{array}{l}36 . \\
7\end{array}$ & $\begin{array}{l}2 \\
5\end{array}$ & $\begin{array}{l}31 . \\
6\end{array}$ & 3.94 & $\begin{array}{l}0.9 \\
4\end{array}$ \\
\hline \multicolumn{12}{|c|}{ 4. I am familiar with buying materials on the internet } \\
\hline 0 & .0 & 8 & $\begin{array}{l}9 . \\
9\end{array}$ & $\begin{array}{l}2 \\
1\end{array}$ & $\begin{array}{l}25 . \\
9\end{array}$ & $\begin{array}{l}3 \\
7\end{array}$ & $\begin{array}{l}45 . \\
7\end{array}$ & $\begin{array}{l}1 \\
5\end{array}$ & $\begin{array}{l}18 . \\
5\end{array}$ & 3.73 & $\begin{array}{l}0.8 \\
8\end{array}$ \\
\hline & abil & & & & & & & & & 3.96 & $\begin{array}{l}0.6 \\
3\end{array}$ \\
\hline
\end{tabular}

Table II and Figure 8 show that the total of means of the variable total ability to search about desired product online was (3.96), with standard deviation (SD) (0.63), which means this ability was low. Also, it can be noted that question 2 (Q2) "Searching and buying on the internet makes my life easier" had the highest mean (4.16, SD0.96), while Q4"I am familiar with buying materials on the internet" had the lowest mean (3.73, SD0.88) (Table II ).

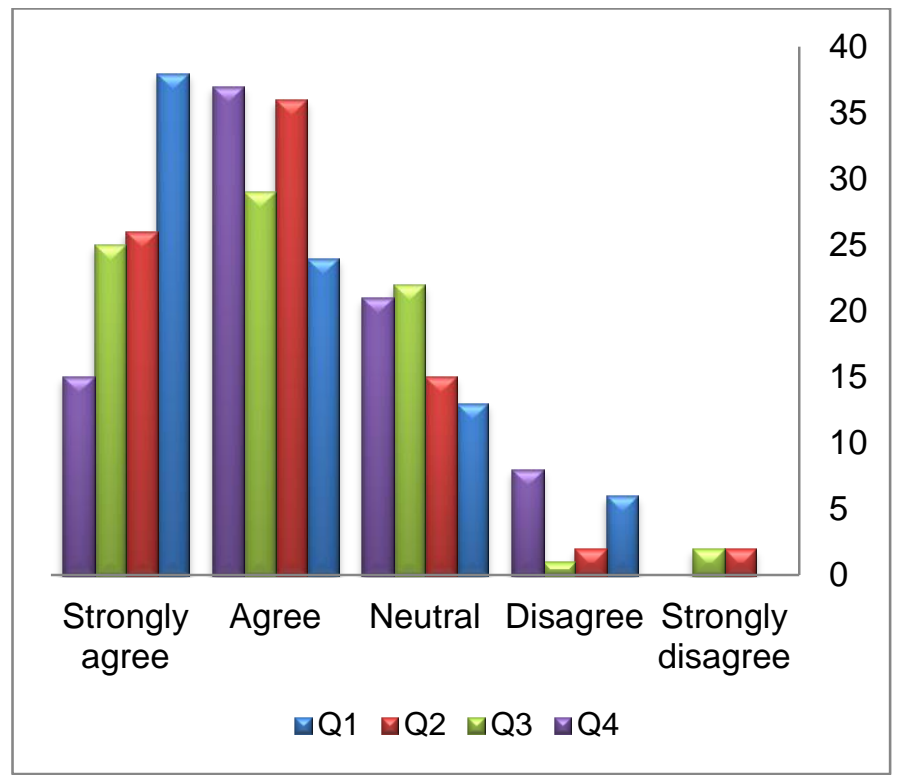

Fig. 8. Ability to search about desired product online
TABLE III. SECTION 2 - Customer's Trust In UsEd ONLINE SHOPPING WEBSITES

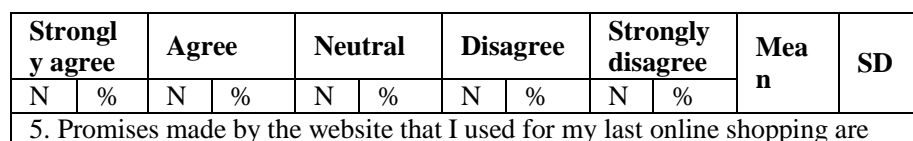

5. Promises made by the website that I used for my last online shopping are likely to be reliable

\begin{tabular}{|l|l|l|l|l|l|l|l|l|l|l|l|}
\hline 2 & 2. & 4 & 5.0 & 2 & 32. & 3 & 42. & 1 & 17. & 3.68 & 0.9 \\
& 5 & & & 6 & 5 & 4 & 5 & 4 & 5 & & 1 \\
\hline
\end{tabular}

6. I do not doubt the honesty of the website that I used for my last online shopping

\begin{tabular}{|l|l|l|l|l|l|l|l|l|l|l|l|}
\hline 1 & $\begin{array}{l}1 . \\
3\end{array}$ & 1 & 14. & 1 & 23. & 2 & 35. & 2 & 25. & 3.71 & $\begin{array}{l}1.0 \\
5\end{array}$ \\
\hline
\end{tabular}

8 . The websites increase my productivity in searching and purchasing products on the internet

\begin{tabular}{|l|l|l|l|l|l|l|l|l|l|l|l|}
\hline 1 & 1. & 7 & 8.9 & 1 & 20. & 3 & 48. & 1 & 21. & 3.80 & 0.9 \\
\hline 1 & 3 & & & 6 & 3 & 8 & 1 & 7 & 5 & & 3 \\
\hline 12.
\end{tabular}
honest

\begin{tabular}{|l|l|l|l|l|l|l|l|l|l|l|l|}
\hline 0 & .0 & 5 & 6.2 & $\begin{array}{l}1 \\
8\end{array}$ & $\begin{array}{l}22 . \\
2\end{array}$ & $\begin{array}{l}3 \\
9\end{array}$ & $\begin{array}{l}48 . \\
1\end{array}$ & $\begin{array}{l}1 \\
9\end{array}$ & $\begin{array}{l}23 . \\
5\end{array}$ & 3.89 & $\begin{array}{l}0.8 \\
4\end{array}$ \\
\hline
\end{tabular}

13. Based on my experience with the online vendor in the past, I know they care about customers

\begin{tabular}{|l|l|l|l|l|l|l|l|l|l|l|l|}
\hline 2 & 2. & 5 & 6.2 & 2 & 33. & 2 & 29. & 2 & 28. & 3.75 & $\begin{array}{l}1.0 \\
7\end{array}$ \\
\hline
\end{tabular}

14. I am very likely to provide the online vendor with the information it needs to better serve my needs

\begin{tabular}{|l|l|l|l|l|l|l|l|l|l|l|l|}
\hline 1 & 1. & 8 & 9.9 & 1 & 17. & 3 & 39. & 2 & 32. & 3.91 & $\begin{array}{l}1.0 \\
0\end{array}$ \\
\hline
\end{tabular}

15. I usually use people ratings and reviews about products on the internet

\begin{tabular}{|l|l|l|l|l|l|l|l|l|l|l|l|}
\hline 1 & 1. & 5 & 6.2 & 1 & 17. & 3 & 43. & 2 & 32. & 3.99 & 0.9 \\
\hline
\end{tabular}

30. I am happy to use my credit card to purchase from an online vendor

\begin{tabular}{|c|c|c|c|c|c|c|c|c|c|c|c|}
\hline 3 & $\begin{array}{l}3 . \\
8\end{array}$ & $\begin{array}{l}1 \\
4\end{array}$ & $\begin{array}{l}17 . \\
5\end{array}$ & $\begin{array}{l}1 \\
8\end{array}$ & $\begin{array}{l}22 . \\
5\end{array}$ & $\begin{array}{l}2 \\
9\end{array}$ & $\begin{array}{l}36 . \\
3\end{array}$ & $\begin{array}{l}1 \\
6\end{array}$ & $\begin{array}{l}20 . \\
0\end{array}$ & 3.51 & $\begin{array}{l}1.1 \\
1\end{array}$ \\
\hline \multicolumn{10}{|c|}{ Customer's trust in used online shopping websites } & 3.83 & $\begin{array}{l}0.5 \\
4\end{array}$ \\
\hline
\end{tabular}

Table III and figure $(9,10)$ show that the total of means of the variable customer's trust in used online shopping websites was 3.83 (SD0.54), which means that trust was low. Also,Q7“The websites on the internet enable me to search and buy materials faster" had the highest mean (4.23, SD0.83), while Q30"I am happy to use my credit card to purchase from an online vendor" had the lowest (3.51, SD1.11). 


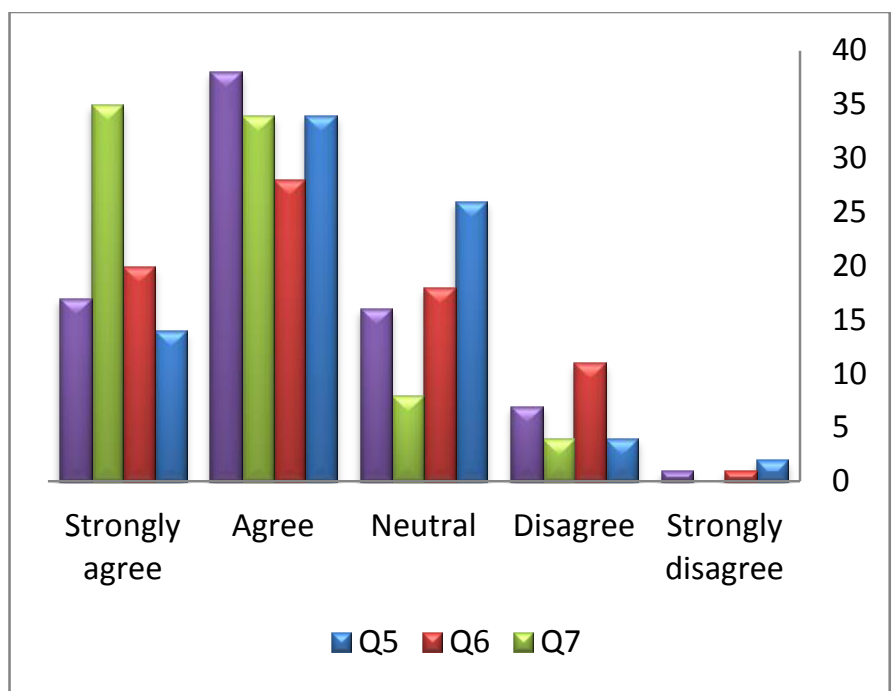

Fig. 9. Customers' trust in used online shopping websites

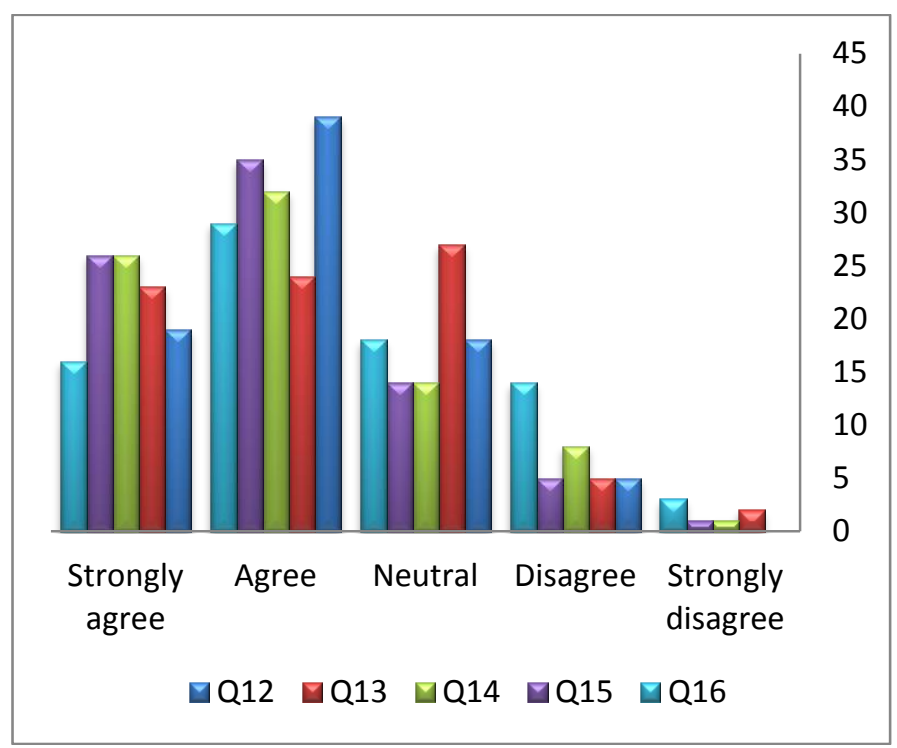

Fig. 10. Customers' trust in used online shopping websites

TABLE IV. SECTION 3 - EFFECT OF FORUMS, COMMUNITIES AND SOCIAL NETWORKING WEBSITES ON CUSTOMERS' ONLINE SHOPPING EXPERIENCE

\begin{tabular}{|c|c|c|c|c|c|c|c|c|c|c|c|}
\hline \multicolumn{2}{|c|}{$\begin{array}{l}\text { Strongl } \\
\text { y agree }\end{array}$} & \multicolumn{2}{|c|}{ Agree } & \multicolumn{2}{|c|}{ Neutral } & \multicolumn{2}{|c|}{ Disagree } & \multicolumn{2}{|c|}{$\begin{array}{l}\text { Strongly } \\
\text { disagree }\end{array}$} & \multirow[t]{2}{*}{$\begin{array}{c}\text { Mea } \\
\mathbf{n}\end{array}$} & \multirow[t]{2}{*}{ SD } \\
\hline $\mathrm{N}$ & $\%$ & $\mathrm{~N}$ & $\%$ & $\mathrm{~N}$ & $\%$ & $\mathrm{~N}$ & $\%$ & $\mathrm{~N}$ & $\%$ & & \\
\hline \multicolumn{12}{|c|}{ 9. I am familiar with inquiring about material ratings on the internet } \\
\hline 2 & $\begin{array}{c}2 . \\
6\end{array}$ & 5 & 6.5 & $\begin{array}{l}2 \\
2\end{array}$ & $\begin{array}{c}28 . \\
6\end{array}$ & $\begin{array}{l}2 \\
5\end{array}$ & $\begin{array}{c}32 . \\
5\end{array}$ & $\begin{array}{l}2 \\
3\end{array}$ & $\begin{array}{c}29 . \\
9\end{array}$ & 3.81 & $\begin{array}{c}1.0 \\
3\end{array}$ \\
\hline \multicolumn{12}{|c|}{ 10. I trust my friends on online forums and communities } \\
\hline 3 & $\begin{array}{l}3 . \\
8\end{array}$ & $\begin{array}{l}1 \\
2\end{array}$ & $\begin{array}{c}15 . \\
0\end{array}$ & $\begin{array}{l}1 \\
3\end{array}$ & $\begin{array}{c}16 . \\
3\end{array}$ & $\begin{array}{l}3 \\
1\end{array}$ & $\begin{array}{c}38 . \\
8\end{array}$ & $\begin{array}{l}2 \\
1\end{array}$ & $\begin{array}{c}26 . \\
3\end{array}$ & 3.69 & $\begin{array}{c}1.1 \\
3\end{array}$ \\
\hline \multicolumn{12}{|c|}{$\begin{array}{l}\text { 11. I use online forums and communities for acquiring information about a } \\
\text { product }\end{array}$} \\
\hline 2 & $\begin{array}{l}2 . \\
6\end{array}$ & 6 & 7.7 & $\begin{array}{l}1 \\
6\end{array}$ & $\begin{array}{c}20 . \\
5\end{array}$ & $\begin{array}{l}3 \\
2\end{array}$ & $\begin{array}{c}41 . \\
0\end{array}$ & $\begin{array}{l}2 \\
2\end{array}$ & $\begin{array}{c}28 . \\
2\end{array}$ & 3.85 & $\begin{array}{c}1.0 \\
1\end{array}$ \\
\hline & $\begin{array}{l}\text { ffec } \\
\text { web }\end{array}$ & & ns, & $\mathrm{im}$ & ties & Isc & $\begin{array}{l}\text { lne } \\
\text { exp }\end{array}$ & ork & & 3.78 & $\begin{array}{c}.79 \\
0\end{array}$ \\
\hline
\end{tabular}

Table VI and figure 11 show that the total of means of the variable effect of forums, communities and social networking websites on customers' online shopping experience was 3.78 (SD0.79), which means that this effect was low. Also,Q11"I use online forums and communities for acquiring information about a product" had the highest mean (3.85, SD1.01), while Q10"I trust my friends on online forums and communities" had the lowest (3.69, SD1.13).

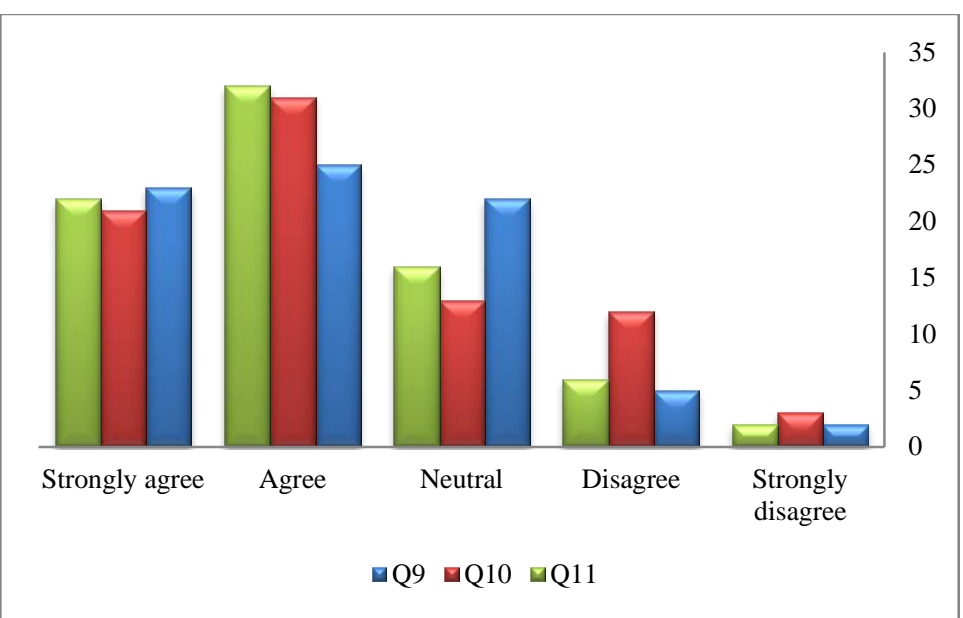

Fig. 11. Effect of forums, communities and social networking websites on customers' online shopping experience

TABLE V. SECTION Four - LEARNING TO USE COMPUTERS AND INTERNET FOR SHOPPING

\begin{tabular}{|c|c|c|c|c|c|c|c|c|c|c|c|}
\hline \multicolumn{2}{|c|}{$\begin{array}{l}\text { Strongl } \\
\text { y agree }\end{array}$} & \multicolumn{2}{|c|}{ Agree } & \multicolumn{2}{|c|}{ Neutral } & \multicolumn{2}{|c|}{ Disagree } & \multicolumn{2}{|c|}{$\begin{array}{l}\text { Strongly } \\
\text { disagree }\end{array}$} & \multirow[t]{2}{*}{$\begin{array}{c}\text { Mea } \\
\text { n }\end{array}$} & \multirow[t]{2}{*}{ SD } \\
\hline $\mathrm{N}$ & $\%$ & $\mathrm{~N}$ & $\%$ & $\mathrm{~N}$ & $\%$ & $\mathrm{~N}$ & $\%$ & $\mathrm{~N}$ & $\%$ & & \\
\hline \multicolumn{12}{|c|}{ 16. It is easy to become skilful at using the websites } \\
\hline \multirow[t]{2}{*}{3} & 3. & 2 & 2.5 & 1 & 12. & 3 & 45. & 2 & 36. & 4.07 & 0.97 \\
\hline & 8 & & & 0 & 5 & 6 & 0 & 9 & 3 & & \\
\hline \multicolumn{12}{|c|}{ 17. Learning to operate the websites on the internet is easy } \\
\hline \multirow[t]{2}{*}{1} & 1. & 4 & 5.1 & 1 & 1.3 & 3 & 38. & 4 & 54. & 4.39 & 0.85 \\
\hline & 3 & & & & & 0 & 0 & 3 & & & \\
\hline \multicolumn{12}{|c|}{ 27. I have had training to use computers and the internet } \\
\hline \multirow[t]{2}{*}{3} & 3. & 1 & 16. & 1 & 15. & 2 & 30. & 2 & 33. & 3.73 & 1.20 \\
\hline & 8 & 3 & 7 & 2 & 4 & 4 & 8 & 6 & 3 & & \\
\hline \multicolumn{12}{|c|}{ 28. I have learned to use the internet to shop online } \\
\hline \multirow[t]{2}{*}{1} & 1. & 1 & 18. & 1 & 13. & 2 & 36. & 2 & 31. & 3.78 & 1.12 \\
\hline & 3 & 4 & 2 & 0 & 0 & 8 & 4 & 4 & 2 & & \\
\hline \multicolumn{12}{|c|}{ 29. My learning and training is/was useful for online shopping } \\
\hline \multirow[t]{2}{*}{1} & 1. & 7 & 9.1 & 1 & 13. & 3 & 39. & 2 & 37. & 4.03 & 1.00 \\
\hline & 3 & & & 0 & 0 & 0 & 0 & 9 & 7 & & \\
\hline \multicolumn{10}{|c|}{ mine learning to use computers and internet for shopping } & 4.00 & $\begin{array}{c}0.69 \\
9\end{array}$ \\
\hline
\end{tabular}

Table $\mathrm{V}$ and figure 12 show that the total of means of the variable examine learning to use computers and internet for shopping was 4.00 (SD0.699), which indicates a low level of learning to use computers and internet for shopping. Also, Q17"Learning to operate the websites on the internet is easy" had the highest mean (4.39, SD0.85), while Q27"I have had training to use computers and the internet" had the lowest (3.73, SD1.20). 


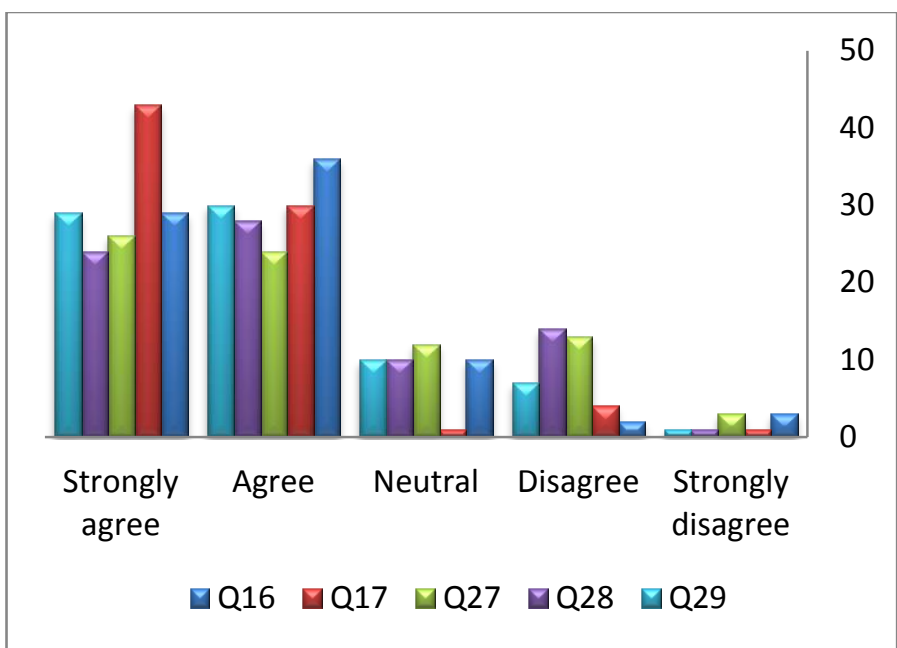

Fig. 12. Learning to use computers and internet for shopping

TABLE VI. SECTION FIVE - INTERACTING WITH VENDER VIA ONLINE SHOPPING WEBSITES

\begin{tabular}{|c|c|c|c|c|c|c|c|c|c|c|c|}
\hline \multicolumn{2}{|c|}{$\begin{array}{c}\text { Strongly } \\
\text { agree }\end{array}$} & \multicolumn{2}{|c|}{ Agree } & \multicolumn{2}{|c|}{ Neutral } & \multicolumn{2}{|c|}{ Disagree } & \multicolumn{2}{|c|}{$\begin{array}{l}\text { Strongly } \\
\text { disagree }\end{array}$} & \multirow[t]{2}{*}{$\begin{array}{c}\text { Mea } \\
\text { n }\end{array}$} & \multirow[t]{2}{*}{ SD } \\
\hline $\mathrm{N}$ & $\%$ & $\mathrm{~N}$ & $\%$ & $\mathrm{~N}$ & $\%$ & $\mathrm{~N}$ & $\%$ & $\mathrm{~N}$ & $\%$ & & \\
\hline \multicolumn{12}{|c|}{ 19. The website that I use for my online shopping is flexible to interact with } \\
\hline 3 & $\begin{array}{l}3 . \\
8\end{array}$ & 1 & 1.3 & $\begin{array}{l}1 \\
2\end{array}$ & $\begin{array}{c}15 . \\
4\end{array}$ & $\begin{array}{l}3 \\
0\end{array}$ & 38. & $\begin{array}{l}3 \\
2\end{array}$ & $\begin{array}{c}41 . \\
0\end{array}$ & 4.12 & $\begin{array}{c}0.9 \\
8\end{array}$ \\
\hline \multicolumn{12}{|c|}{$\begin{array}{l}\text { 20. My interaction with the websites in the internet is clear and } \\
\text { understandable }\end{array}$} \\
\hline 1 & $\begin{array}{l}1 . \\
3\end{array}$ & 5 & 6.3 & $\begin{array}{l}1 \\
7\end{array}$ & $\begin{array}{c}21 . \\
3\end{array}$ & $\begin{array}{l}3 \\
8\end{array}$ & $\begin{array}{c}47 . \\
5\end{array}$ & $\begin{array}{l}1 \\
9\end{array}$ & $\begin{array}{c}23 . \\
8\end{array}$ & 3.86 & $\begin{array}{c}0.9 \\
0\end{array}$ \\
\hline \multicolumn{12}{|c|}{$\begin{array}{l}\text { 21. There is a sense of human warmth in the website that I use for my online } \\
\text { shopping }\end{array}$} \\
\hline 5 & $\begin{array}{l}6 . \\
4 \\
\end{array}$ & 6 & 7.7 & $\begin{array}{l}1 \\
6 \\
\end{array}$ & $\begin{array}{c}20 . \\
5 \\
\end{array}$ & $\begin{array}{l}2 \\
7 \\
\end{array}$ & $\begin{array}{c}34 . \\
6 \\
\end{array}$ & $\begin{array}{l}2 \\
4 \\
\end{array}$ & $\begin{array}{c}30 . \\
8 \\
\end{array}$ & 3.76 & $\begin{array}{c}1.1 \\
6 \\
\end{array}$ \\
\hline \multicolumn{12}{|c|}{ 22. I perceive myself pretty experienced in using the computer } \\
\hline 3 & $\begin{array}{r}4 . \\
0 \\
\end{array}$ & 2 & 2.7 & 6 & 8.0 & $\begin{array}{l}4 \\
0 \\
\end{array}$ & $\begin{array}{c}53 . \\
3 \\
\end{array}$ & $\begin{array}{l}2 \\
4 \\
\end{array}$ & $\begin{array}{c}32 . \\
0\end{array}$ & 4.07 & $\begin{array}{c}0.9 \\
4 \\
\end{array}$ \\
\hline \multicolumn{12}{|c|}{ 23. I perceive myself pretty experienced in using the internet } \\
\hline 2 & $\begin{array}{c}2 . \\
6 \\
\end{array}$ & 3 & 3.9 & $\begin{array}{l}1 \\
2 \\
\end{array}$ & $\begin{array}{c}15 . \\
8\end{array}$ & $\begin{array}{l}2 \\
6 \\
\end{array}$ & $\begin{array}{c}34 . \\
2\end{array}$ & $\begin{array}{l}3 \\
3\end{array}$ & $\begin{array}{c}43 . \\
4\end{array}$ & 4.12 & $\begin{array}{c}0.9 \\
9\end{array}$ \\
\hline \multicolumn{12}{|c|}{ 24. I have been using the internet for a long time } \\
\hline 3 & $\begin{array}{l}3 . \\
8\end{array}$ & 7 & 8.9 & $\begin{array}{l}1 \\
0 \\
\end{array}$ & $\begin{array}{c}12 . \\
7\end{array}$ & $\begin{array}{l}3 \\
1 \\
\end{array}$ & $\begin{array}{c}39 . \\
2\end{array}$ & $\begin{array}{l}2 \\
8 \\
\end{array}$ & $\begin{array}{c}35 . \\
4\end{array}$ & 3.94 & $\begin{array}{c}1.0 \\
9 \\
\end{array}$ \\
\hline \multicolumn{12}{|c|}{ 25. There is a sense of human contact in the website } \\
\hline 0 & .0 & 6 & 7.5 & $\begin{array}{l}1 \\
8\end{array}$ & $\begin{array}{c}22 . \\
5\end{array}$ & $\begin{array}{l}3 \\
5\end{array}$ & $\begin{array}{c}43 . \\
8\end{array}$ & $\begin{array}{l}2 \\
1\end{array}$ & $\begin{array}{c}26 . \\
3\end{array}$ & 3.89 & $\begin{array}{c}0.8 \\
9\end{array}$ \\
\hline \multicolumn{12}{|c|}{$\begin{array}{l}\text { 26. There is a sense of sociability in the website that I use for internet } \\
\text { shopping }\end{array}$} \\
\hline 1 & 1. & 9 & $\begin{array}{c}11 . \\
4\end{array}$ & $\begin{array}{l}1 \\
6\end{array}$ & $\begin{array}{c}20 . \\
3\end{array}$ & $\begin{array}{l}3 \\
7\end{array}$ & $\begin{array}{c}46 . \\
8\end{array}$ & $\begin{array}{l}1 \\
6\end{array}$ & $\begin{array}{c}20 . \\
3\end{array}$ & 3.73 & $\begin{array}{c}0.9 \\
6\end{array}$ \\
\hline & Exan & 101 & eract & wit & rende & & line & & & 3.92 & $\begin{array}{c}0.6 \\
4\end{array}$ \\
\hline
\end{tabular}

Table VI and figure $(13,14)$ show that the total of means of the variable examine interacting with vender via online shopping websites was 3.92 (SD0.64), which indicates a low level of such behavior. Also, Q19 "The website that I use for my online shopping is flexible to interact with" and (23) "I perceive myself pretty experienced in using the internet" had the highest mean (4.12, SD0.98, 0.99 respectively), while Q26“There is a sense of sociability in the website that I use for internet shopping" had the lowest (3.73, SD0.96).

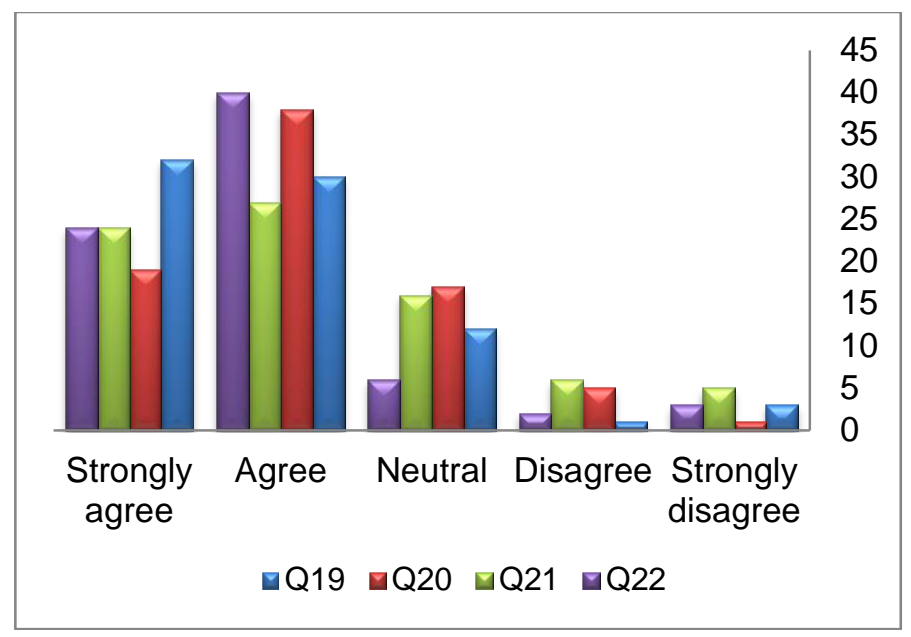

Fig. 13. Interacting with vender via online shopping websites, Q19-22

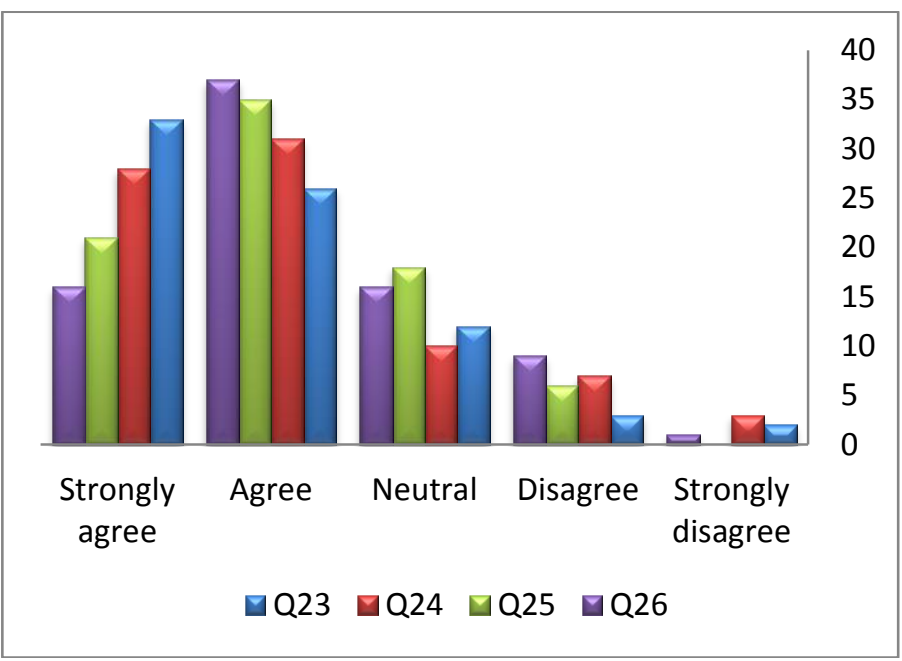

Fig. 14. Interacting with vender via online shopping website, Q23-26

TABLE VII. MEANS, SDS AND T-TeST FOR THE GENDER OF THE MEMBERS OF THE STUdy SAMPLE ON THE SECTIONS

\begin{tabular}{|c|c|c|c|c|c|c|c|}
\hline Gender & $\mathbf{N}$ & Mean & SD & $\begin{array}{c}\text { Std. } \\
\text { error } \\
\text { mean }\end{array}$ & $\mathbf{t}$ & df & $\begin{array}{c}\text { Sig. } \\
(2- \\
\text { tailed) }\end{array}$ \\
\hline \multicolumn{8}{|c|}{ Ability to search about desired product online } \\
\hline M & 38 & 4.06 & .627 & .102 & 1.375 & 79 & .173 \\
\hline $\mathrm{F}$ & 43 & 3.87 & .623 & .095 & 1.374 & 77.638 & .173 \\
\hline \multicolumn{8}{|c|}{ Customer's trust in used online shopping websites } \\
\hline $\mathrm{M}$ & 38 & 3.86 & .572 & .093 & .494 & 79 & .623 \\
\hline $\mathrm{F}$ & 43 & 3.80 & .512 & .078 & .491 & 74.866 & .625 \\
\hline \multicolumn{8}{|c|}{$\begin{array}{l}\text { Effect of forums, communities and social networking websites on customers' } \\
\text { online shopping experience }\end{array}$} \\
\hline M & 38 & 3.82 & .777 & .126 & .426 & 79 & .672 \\
\hline $\mathrm{F}$ & 43 & 3.74 & .813 & .124 & .427 & 78.510 & .671 \\
\hline \multicolumn{8}{|c|}{ Examine learning to use computers and internet for shopping } \\
\hline M & 38 & 4.07 & .807 & .131 & .822 & 79 & .413 \\
\hline $\mathrm{F}$ & 43 & 3.94 & .590 & .090 & .807 & 67.002 & .423 \\
\hline \multicolumn{8}{|c|}{ Examine interacting with vender via online shopping websites } \\
\hline $\mathrm{M}$ & 37 & 3.90 & .727 & .120 & $-.321-$ & 78 & .749 \\
\hline$F$ & 43 & 3.94 & .554 & .084 & $-.315-$ & 66.659 & .754 \\
\hline
\end{tabular}

Table VII and figure 15 show that the significance value for all sections is greater than, 05 , which means that there are no 
statistically significant differences in all sections between males and females.

\section{CRITICAl Evaluation OF Results}

As stated in research methodology section, a questionnaire was distributed in several branches of PGS. The questionnaire was filled by random customers who attend this shop randomly and voluntary. These customers represent a population of Jordanian society and their opinion towards E-commerce adoption that is generally representative for other SMEs in the HKJ. Nevertheless, the insights of this mainly concerned the particular vision of PGS customers' enthusiasm for their vendor's migration into E-commerce.

The results that obtained from the survey conducted showed that $57.4 \%$ of participants had no online shopping experience, while $42.6 \%$ had some online experience. Based on literature review studies about E-commerce in Jordan, previous studies identified the impacts of society culture, with results generally affirming more online shoppers than expected, despite the entrenched Jordanian societal cultural preference for traditional shopping formats.

However, the fact that the survey was conducted in Amman, the capital of $\mathrm{HKJ}$, is an important consideration. Amman represents the most prosperous city in the country where all required services are available, including education and other facilities (e.g. internet infrastructure). Furthermore, most of the respondents are relatively recent graduates $(74.7 \%)$ aged 20-25 years old (37.8\%),representing the most computer literate segment of Jordanian society; older and less educated portions of the population - most of whom would benefit most from E-commerce applications -are not represented. The majority of participants $(66.7 \%)$ were females, but no gender effect was determined by the t-test of the study samples in all sections.

The most striking finding of the study is that the majority of respondents did not have direct online shopping experience, which demonstrates the fact that Jordanian societal culture has a major effect on organizations' intention to move towards Ecommerce; put simply, organizations do not seriously contemplate developing their E-commerce activities, and the majority of people in local society are unresponsive to such initiatives.

Generally, HKJ as previously stated in literature review, is a developing country with limited resources that needs enhancement to accept the E-commerce adoption. Given the lack of interest among the public and SMEs, the government must play a more active role in facilitating E-commerce with appropriate infrastructure and expanding E-commerce knowledge to people across the country. This may be spearheaded by the full implementation of the ambition Egovernment project in the country, which may encourage more people across the country to gain more knowledge of Ecommerce potential based on their experience of the convenience of E-government facilities for taxation, public services fees and transaction payments online, circumventing the cumbersome bureaucracy of traditional interactions with the government. This will erode Jordanians' fears of local organizations' E-commerce adoption and increase their enthusiasm about E-commerce generally, promoting the development of serious strategies to apply and benefit from this change.

Local E-commerce companies should be actively encouraged and motivated by incentives, such as the elimination of sales tax for E-commerce transactions for a probationary period in order to encourage private sector companies to conduct serious steps towards adopting Ecommerce.

Finally, based upon previous researches conducted on Ecommerce adoption in Jordan and results of this research, it highly recommended that PGS in particular wait a period of time (i.e. a minimum of two years) to begin changes preparatory for the serious adoption of E-commerce in their business operations due to market uncertainties at the present juncture.

\section{CONCLUSIONS}

It can be concluded that Jordanian society is strongly attached to traditional ways of shopping, but the upcoming generations, represented by fresh graduates in this study, are increasingly experienced and accepting of the potential of online shopping experiences. This means that changes in consumer behavior (i.e. shopping trends) can be anticipated in the near future, with the diffusion of more advanced computer literacy throughout Jordanian society. Furthermore, increased usages of SNS in Jordanian society in daily life is affecting shopping behavior regardless of age category.

In conclusion, SMEs are encouraged to prepare a plan, design and implement the migration towards adopting full Ecommerce activities to encompass the development of Jordanian customers' acceptance of online shopping.

\section{REFERENCES}

[1] P. Permwanichagun, S. Kaenmanee, and A. Naipinit, "The External Environments Factors Affecting Success For Implementation: In Context Of Sole Proprietorship E-Commerce Entrepreneurs In Thailand". International Business Management, Vol. 9, pp. 122-127. 2014

[2] M. Aljaber, "The impact of privacy regulations on the development of electronic commerce in Jordan and the UK", Doctorat thesis, De Montfort University, UK, 2012.

[3] S. Mariotti, F. Sgobbi, "Alternative paths for the growth of e-commerce". Futures 33(2):109-125 - March 2001

[4] M. Yasin, M., Alavi, J., Czuchry, A. and Shafieyoun, R.,"An exploratory investigation of factors shaping electronic commerce practices in Iran: Benchmarking the role of technology and culture", Benchmarking: An International Journal, Vol. 21(5), pp.775$791,2014$.

[5] S. Allahawiah, H. Altarawneh, and S. Alamro "The Internet and Small Medium-Sized Enterprises (SMES) in Jordan". World academy of Science, Engineering and technology, Vol. 62, pp.302-306, 2010.

[6] N. Terzi, "The impact of e-commerce on international trade and employment". Procedia-Social and Behavioral Sciences, Vol. 24, pp.745-753. 2011.

[7] M. Khoshnampour and M. Nosrati, "An overview of Ecommerce”.World Applied Programming, Vol. 1(2), pp.94-99. 2011.

[8] R. Zaker and A. Ansari, "Towards Improving Quality of E-Commerce Websites in Hospitals". Istanbul, Turkey MAY 8-10, 2013.

[9] Z. Huang, and M. Benyoucef, " From e-commerce to social commerce: A close look at design features". Electronic Commerce Research and Applications, Vol. 12(4), pp.246-259. 2013. 
[10] E. Turban, D. King, J. Lee, T. Liang, and D. Turban, "Electronic commerce: A managerial and social networks perspective". Springer.2015.

[11] G. Nielson, B. Pasternack, A. Viscio, "Up the (E) organization! A seven-dimensional model for the centerless enterprise". Managing Mag [e-journal], Vol. 18, pp.52-61 (First Quarter). 2000.

[12] W. Hong, K. Zhu, "Migrating to internet-based e-commerce: Factors affecting E-commerce adoption and migration at the firm level". Information \& Management [e-journal], Vol. 43, pp.204-221. 2006.

[13] S. Lippert, and C. Govindarajulu, "Technological, organizational, and environmental antecedents to web services adoption". Communications of the IIMA, Vol. 6(1), p.14. 2015.

[14] R. Lituchy, "Bed and breakfasts, small inns, and the internet: the impact of technology on the globalization of small businesses". Journal of International Marketing, Vol. 8(2), pp. 86-97. 2000.

[15] J. George, "Influences on the intent to make Internet purchases". Internet Research-Electronic Networking Applications and Policy, Vol. 12, pp. 165-180. 2002.

[16] A. Charlesworth, "Digital marketing: A practical approach". Routledge, 2014.

[17] S. Drew, "E-Business research practice: towards an agenda". Electronic Journal on Business Research Methods Vol. 1(1). pp.18-26. 2002.
[18] R. Stair, and G. Reynolds, "Principles of Information Systems". (Third Edition). Course Technology a division of Thomson Learning, Inc: Canada. 2003.

[19] M. Abbad, R. Abbad, and M. Saleh, "Limitations of e-commerce in developing countries: Jordan case", Education, Business and Society: Contemporary Middle Eastern Issues, Vol. 4 Iss: 4, pp.280 - 291, 2011.

[20] M. Al-debei, "The current state of e-commerce in Jordan: applicability and future prospects "an empirical study"”. University of Jordan elibrary.2005.

[21] S. Alamro, S. Tarawneh, "Factors Affecting E-Commerce Adoption in Jordanian SMEs. European Journal of Scientific Research. Vol. 64(4), pp.497-506.. 2011.

[22] A. Al-Bakri, M. Katsioloudes,"The factors affecting e-commerce adoption by Jordanian SMEs", Management Research Review, Vol. 38 Iss: 7, pp.726 - 749, 2015.

[23] M. Hajli, H. Bugshan, M. Hajli, and A. Kalantari, "E-Commerce PreAdoption Model for SMEs in Developing Countries". In Proceedings of the 2012 International Conference on e-Learning, e-Business, Enterprise Information Systems, and e-Government, Las Vegas, United States.2012. 